JOURNAL OF NURSING EDUCATION AND PRACTICE,

VOL. 01 NO. 01 DESEMBER 2020
Ciptaan disebarluaskan di bawah

Lisensi Creative Commons Atribusi-

NonKomersial-BerbagiSerupa 4.0

\title{
ORIGAMI SEBAGAI TINDAKAN ADJUVANT ATRAUMATIC CARE TERHADAP TINGKAT KECEMASAN ANAK YANG MENJALANI HOSPITALISASI DI RSUD 45 KUNINGAN
}

\author{
Neneng Aria Nengsih
}

STIKes Kuningan

Nenengarianengsih@gmail.com

\begin{abstract}
Abstrak
Latar belakang: Ketika anak sakit dan mengharuskan dirawat di rumah sakit, membuat cemas anak dan keluarga karena harus berusaha beradaptasi dengan lingkungan asing. Salah satu intervensi keperawatan untuk membantu mengurangi kecemasan pada anak selama menjalani hospitalisasi adalah terapi bermain origami. Tujuan penelitian: menganalisis rerata tingkat kecemasan sebelum dan sesudah diberikan terapi origami pada anak usia prasekolah yang menjalani prosedur invasif infus saat hospitalisasi di Ruang Anak RSUD 45 Kuningan.

Metode penelitian: jenis penelitian ini adalah Pra Eksperimen dengan rancangan One Group Pretest And Posttest. Jumlah sampel dalam penelitian ini sebanyak 15 responden dengan menggunakan teknik Purposive Sampling. Pengambilan data dilakukan dengan cara mengukur tingkat kecemasan sebelum dan sesudah diberikan terapi bermain origami yang diukur menggunakan Preschool Anxiety Scale-Revised (2010). Selanjutnya data diolah dan dianalisis menggunakan uji Wilcoxon Signed Rank-test.

Hasil penelitian menunjukkan bahwa rerata tingkat kecemasan responden sebelum diberikan intervensi adalah sebesar 1,93 dan rerata sesudah diberikan intervensi terapi bermain origami adalah sebesar 1,20. Selisih rata-rata tingkat kecemasan sebelum dan sesudah dilakukan terapi adalah 0,73. Hasil uji statistik wilcoxon tentang pengaruh terapi bermain origami terhadap penurunan tingkat kecemasan pada anak prasekolah yang menjalani hospitalisasi dengan tingkat kepercayaan 95\% $(\alpha=0,05)$ sebesar P value $(0,002)$ dengan demikian $\mathrm{p}$ value $<0,05)$, maka $\mathrm{H} 0$ ditolak. Hal ini berarti terdapat perbedaan tingkat kecemasan sebelum dan sesudah diberikan terapi bermain origami. Sehingga dapat disimpulkan bahwa ada pengaruh pemberian terapi bermain origami terhadap tingkat kecemasan anak yang menjalani prosedur invasif infus saat hospitalisasi di rumah sakit.
\end{abstract}


JOURNAL OF NURSING EDUCATION AND PRACTICE,

VOL. 01 NO. 01 DESEMBER 2020
Ciptaan disebarluaskan di bawah

Lisensi Creative Commons Atribusi-

NonKomersial-BerbagiSerupa 4.0

Diharapkan hasil penelitian ini dapat dikembangkan oleh peneliti lain terkait metode adjuvant lain yang dapat menurunkan tingkat kecemasan pada anak sebagai tindakan atraumatic care.

Kata kunci : hospitalisasi, kecemasan, origami

\section{Pendahuluan}

\section{Latar Belakang}

Penyakit dan hospitalisasi seringkali menjadi masalah utama yang harus dihadapi anak. Hospitalisasi memberikan efek pada anak sebelum, selama hospitalisasi dan setelah pulang dari rumah sakit (Hockenberry \& Wilson, 2015; BsiriMoghaddam et al., 2011). Hospitalisasi merupakan suatu keadaan krisis pada anak, saat sakit dan dirawat di rumah sakit, keadaan ini terjadi karena anak harus berusaha untuk beradaptasi dengan lingkungan asing dan baru sehingga menjadi faktor stressor bagi anak maupun orang tua, dan keluarga (Gomes et al., 2016; Hockenberry \& Wilson, 2015; Utami, 2014).

Faktor stressor anak saat menjalani hospitalisasi diantaranya tindakan invasif baik menyakitkan atau tidak merupakan suatu ancaman bagi anak usia prasekolah karena mereka menganggap bahwa tindakan invasif merupakan sumber kerusakan terhadap integritas tubuhnya. Menurut Kozlowski \& Monitto, (2013) walaupun anak menerima prosedur tindakan yang lebih menyakitkan, mereka sering menganggap prosedur yang bersifat "tusukan" sebagai prosedur tindakan yang paling menyakitkan. Kecemasan yang dialami anak prasekolah selama hospitalisasi jika tidak segera ditangani akan menghambat proses kesembuhan anak karena anak akan melakukan penolakan terhadap perawatan dan pengobatan yang diberikan (Ball \& Bindler, 2013; Hockenberry \& Wilson, 2015; Sadiah et al., 2014).

Di Amerika Serikat diperkirakan lebih dari 5 juta anak mengalami hospitalisasi dan lebih dari 50\% anak mengalami kecemasan dan stress. Injury dan berbagai penyebab lain menjadi alasan anak menjalani hospitalisasi yang diperkirakan lebih dari 1,6 juta anak dan diantaranya adalah anak usia antara 2-6 tahun (Disease Control, National Hospital Discharge Survey (NHDS), 2004 dalam Kaluas et al., 2015).

Fakta yang didapatkan dari hasil observasi peneliti terhadap 5 anak usia 3-6 
JOURNAL OF NURSING EDUCATION AND PRACTICE,

VOL. 01 NO. 01 DESEMBER 2020

tahun yang mendapatkan prosedur invasif dari tindakan infus di RSUD 45 Kuningan 1 anak tampak tertidur, 1 anak sedang mendengarkan musik dangdut dari Handphone milik orang tuanya sedangkan 3 diantaranya anak tampak cemas, marah, berteriak-teriak memanggil orang tuanya, berbicara kasar, menangis, sedih, dan takut sehingga tidak kooperatif dengan petugas kesehatan. Fakta tersebut diperkuat oleh laporan dari orang tua yang menyatakan anak menolak makan, dan sering bertanya kenapa harus ditusuk jarum yang menyakitkan selain itu waktu tidur sering terbangun karena mimpi buruk. Hal ini kemungkinan terjadi karena anak tidak memahami alasan kenapa harus di rawat, stress dengan adanya perubahan status kesehatan, lingkungan dan kebiasaan sehari-hari serta keterbatasan mekanisme koping yang menyebabkan trauma pada anak (Hockenberry \& Wilson, 2015; Utami, 2014).

Pengalaman yang traumatik dan penuh kecemasan serta ancaman langsung bagi rasa aman adalah dampak negatif dari hospitalisasi pada anak yang dapat berpengaruh terhadap emosional, sosial, dan fisiologis anak. Kondisi tersebut dianggap patologis ketika terdapat stimulus yang tinggi sehingga menyebabkan
Ciptaan disebarluaskan di bawah

Lisensi Creative Commons Atribusi-

NonKomersial-BerbagiSerupa 4.0 Internasional. (c) (7)(2)

gangguan fisik dan psikologis serta berdampak terhadap perkembangan anak selanjutnya yaitu anak akan takut dengan lingkungan baru, hilang kontrol terhadap dirinya sendiri, lebih sering menangis, manja dan agresif, bahkan mengalami depresi dan regresi atau kemunduran perkembangan (Gomes et al., 2016; Hockenberry \& Wilson, 2015; Kaluas et al., 2015; Kozier, 2010; Obaid, 2015; Sadiah et al., 2014; Suryanti \& Yulistiani, 2011).

Alasan tersebut menuntut perawat untuk memberikan pelayanan perawatan yang berkualitas kepada anak maupun orang tua dengan pelaksanaan atraumatic care sebagai intervensi farmakologis dan nonfarmakologis melalui terapi bermain terhadap pasien anak-anak dalam menghadapi prosedur yang berpotensi menyakitkan dan/ atau memprovokasi kecemasan Boseman, (2017) dengan tujuan meminimalkan kecemasan dari tekanan fisik dan psikologis saat hospitalisasi dengan menumbuhkan aspek perkembangan anak secara optimal dan maksimal (Hockenberry \& Wilson, 2015; Mediani, 2017).

Bermain adalah dunia alami untuk anak. American Academy of Pediatrics mengeluarkan pernyataan tentang pentingnya bermain untuk perkembangan 
JOURNAL OF NURSING EDUCATION AND PRACTICE,

VOL. 01 NO. 01 DESEMBER 2020

anak yang sehat. Anak-anak belajar tentang diri sendiri, orang lain, dan dunia mereka melalui bermain (Homeyers \& Morrison, 2008). Terapi bermain merupakan salah satu metode yang digunakan dalam membantu anak-anak mengatasi situasi stres dengan memungkinkan mereka mengungkapkan perasaan mengekspresikan ketakutan dan kecemasan sehingga mendapatkan kontrol atas pengalaman stres dengan memberikan pilihan pada anak-anak untuk menciptakan peristiwa menyenangkan dalam kehidupannya (Andriana, 2011; Nabors et al., 2013).

Hasil evidence membuktikan bahwa banyak jenis permainan yang disukai anak prasekolah diantaranya adalah bercerita dengan dongeng, puzzle, play-dough/clay berupa lilin lembut, boneka perwakilan dengan ukuran yang sama dengan anak, objek rumah sakit, cerita, buku mewarnai dengan semua langkah pengobatan, tanah liat molding, lukisan, video game dan kartun yang diproyeksikan pada langitlangit ruang perawatan selama prosedur, video tentang operasi dengan gambar lingkungan menyerupai ruang operasi, kegiatan bermain dengan penggunaan mewarnai gambar, kertas untuk belajar melipat/origami, menggunting dan air (Ball \& Bindler, 2013; Silva et al., 2017).
Ciptaan disebarluaskan di bawah

Lisensi Creative Commons Atribusi-

NonKomersial-BerbagiSerupa 4.0

Internasional. (c) (i) (2)

Hasil penelitian Suryanti \& Yulistiani, (2011) menunjukkan adanya perbedaan tingkat kecemasan sebelum dan sesudah dilakukan terapi bermain mengalami penurunan dengan tehnik mewarnai dan origami. Hasil penelitian sebelumnya menunjukkan bahwa terdapat pengaruh terapi origami terhadap tingkat kecemasan pada anak prasekolah dengan hospitalisasi (Sadiah et al., 2014).

Pada penelitian ini berbeda dengan penelitian sebelumnya, peneliti memilih jenis terapi bermain origami karena cocok diberikan pada anak usia prasekolah yang sedang menjalani perawatan di rumah sakit dan tidak membutuhkan energi banyak, singkat, sederhana, aman serta murah. Selain itu, pada usia prasekolah, anak perlu menguasai berbagai konsep dasar tentang warna, ukuran, bentuk, arah, besaran, dan sebagainya.

Hasil studi pendahuluan yang dilakukan peneliti di ruang anak dan rekam medis RSUD 45 Kuningan didapatkan data dari 3 bulan terakhir Januari sampai dengan Maret 2017 terdapat 104 (28,80\%) anak usia 3-6 tahun (prasekolah) dari jumlah keseluruhan anak yang dirawat 361 di ruang Anak RSUD 45 Kuningan dengan data penyakit terbanyak adalah infeksi viral. 
JOURNAL OF NURSING EDUCATION AND PRACTICE,

VOL. 01 NO. 01 DESEMBER 2020

RSUD 45 Kuningan telah melakukan upaya mengurangi kecemasan/stressor selama hospitalisasi seperti memodifikasi ruangan dengan berbagai warna cat tembok dan gambar menarik serta memperbolehkan anak ditemani oleh satu orang anggota keluarganya, namun sangat disayangkan ruang perawatan anak belum menerapkan terapi bermain sebagai terapi pendamping non farmakologis sebagai manajemen atraumatic care dalam mengatasi masalah kecemasan pada anak selama dirawat di rumah sakit. Adapun yang melaksanakannya baru sebatas oleh mahasiswa Praktik Klinik. Hal ini yang membuat semakin tinggi terjadinya kemungkinan kecemasan pada anak yang menjalani tindakan prosedur invasif di rumah sakit. Menurut salah seorang perawat/CI ruangan mengatakan belum ada Standar Prosedur Operasional (SPO) khusus dalam manajemen kecemasan atraumatik care akibat hospitalisasi pada anak. Upaya perawat yang biasa dilakukan dalam menurunkan kecemasan anak di rumah sakit perawat membujuk anak dan hanya mengajak berkomunikasi saja (laporan hasil wawancara dengan perawat dan petugas kesehatan ruang Anggrek RSUD 45 Kuningan tahun 2017).
Ciptaan disebarluaskan di bawah

Lisensi Creative Commons Atribusi-

NonKomersial-BerbagiSerupa 4.0 Internasional. (c) (7)(2)

Berdasarkan fenomena yang terjadi dan di RSUD 45 belum ada penelitian yang serupa, serta peneliti ingin membuktikan dugaan efektifitas dari metode terapi bermain origami yang dapat menurunkan kecemasan maka perlu dilakukan penelitian mengenai "Pengaruh Terapi Bermain Origami Terhadap Tingkat Kecemasan Anak Usia Prasekolah Yang Menjalani Prosedur Invasif Infus Saat Hospitalisasi Di Rumah Sakit Umum Daerah 45 Kuningan”.

\section{Masalah Penelitian}

Berdasarkan uraian diatas, maka rumusan masalah penelitiannya adalah adakah Pengaruh Terapi Bermain Origami Terhadap Tingkat Kecemasan Anak Usia Prasekolah Yang Menjalani Prosedur Invasif Infus Saat Hospitalisasi Di Rumah Sakit Umum Daerah 45 Kuningan?

\section{Tujuan Penelitian}

Tujuan penelitian yang ingin dicapai adalah untuk mengetahui Pengaruh Pengaruh Terapi Bermain Origami Terhadap Tingkat Kecemasan Anak Usia Prasekolah Yang Menjalani Prosedur Invasif Infus Saat Hospitalisasi Di Rumah Sakit Umum Daerah 45 Kuningan

\section{Metodologi Penelitian}


JOURNAL OF NURSING EDUCATION AND PRACTICE,

VOL. 01 NO. 01 DESEMBER 2020

Penelitian Pra Eksperimen ini menggunakan rancangan One Group Pretest Posttest tanpa kelompok pembanding (kontrol), tetapi setidaknya sudah dilakukan observasi pertama (pretest) yang dapat memungkinkan menguji perubahan-perubahan yang terjadi setelah adanya eksperimen (Notoatmodjo, 2010).

Dalam penelitian ini dilakukan perlakuan terapi bermain origami pada anak usia prasekolah yang menjalani prosedur invasif infus di Ruang Anak RSUD 45 Kuningan. Yang sebelumnya pada hari pertama dilakukan pretest dengan cara tingkat kecemasan anak sebelum diberikan terapi bermain origami. Setelah diberikan perlakuan terapi bermain origami dilakukan posttest dengan cara membagikan kembali kuesioner kemudian melihat hasil rerata tingkat kecemasannya.

Populasi dalam penelitian ini adalah semua anak usia prasekolah (3-6 tahun) yang menjalani hospitalisasi di ruang anggrek Rumah Sakit Umum Daerah Kuningan pada tahun 2014. Pengambilan sampel dilakukan dengan teknik Purposive Sampling yaitu pengambilan sampel yang didasarkan pada suatu pertimbangan tertentu yang dibuat oleh peneliti sendiri, berdasarkan ciri atau sifat-sifat populasi yang sudah diketahui sebelumnya (Polit et
Ciptaan disebarluaskan di bawah

Lisensi Creative Commons Atribusi-

NonKomersial-BerbagiSerupa 4.0 Internasional.

al., 2014). Penentuan besar sampel yang diperlukan dalam penelitian eksperimen ini dengan menggunakan jumlah sampel minimum yaitu berjumlah 15 responden (Sugiyono, 2014).

Teknik pengumpulan data pada penelitian ini dilakukan dengan cara memberikan lembar kuesioner Preschool Anxiety Scale-Revised (2010) untuk mengukur tingkat kecemasan anak sebelum dan sesudah diberikan terapi bermain origami.

Analisis yang digunakan untuk melihat hubungan antara variabel bebas dengan variabel terikat, menggunakan uji statistik Wilcoxon Signed Rank-Test.

\section{Hasil Penelitian}

\section{Analisis Univariat}

Tabel 1. Gambaran distribusi frekuensi Tingkat Kecemasan Anak Prasekolah sebelum diberikan terapi bermain origami pada anak yang menjalani prosedur invasif infus di rumah sakit Khususnya di Ruang Anak RSUD 45 Kuningan

\begin{tabular}{lcc}
\hline $\begin{array}{c}\text { Tingkat Kecemasan } \\
\text { anak }\end{array}$ & F & \% \\
\hline Cemas ringan & 0 & 0 \\
Cemas sedang & 1 & 6,7 \\
Cemas Berat & 14 & 93,3 \\
\hline Jumlah & 15 & 100.0 \\
\hline
\end{tabular}


JOURNAL OF NURSING EDUCATION AND PRACTICE,

VOL. 01 NO. 01 DESEMBER 2020
Ciptaan disebarluaskan di bawah

Lisensi Creative Commons Atribusi-

NonKomersial-BerbagiSerupa 4.0
Berdasarkan tabel 1. di atas dapat dilihat bahwa hampir semua responden termasuk kategori tingkat cemas berat.

Tabel 2. Gambaran distribusi frekuensi Tingkat Kecemasan Anak Prasekolah sesudah diberikan terapi bermain origami pada anak yang menjalani prosedur invasif infus di rumah sakit Khususnya di Ruang Anak RSUD 45 Kuningan

\begin{tabular}{lcc}
\hline $\begin{array}{c}\text { Tingkat Kecemasan } \\
\text { anak }\end{array}$ & F & \% \\
\hline Cemas ringan & 1 & 6,7 \\
Cemas sedang & 10 & 66,7 \\
Cemas Berat & 4 & 26,7 \\
Jumlah & 15 & 100 \\
\hline
\end{tabular}

Berdasarkan tabel 2 di atas dapat dilihat bahwa sebagian besar responden termasuk kategori cemas sedang.

Tabel 3. Gambaran distribusi frekuensi nilai yang dicapai antara tingkat kecemasan sebelum dan sesudah diberikan terapi bermain origami

\begin{tabular}{lcccc}
\hline $\begin{array}{c}\text { Tingkat } \\
\text { Kecemasa } \\
\mathbf{n}\end{array}$ & $\begin{array}{c}\text { Min- } \\
\text { Max }\end{array}$ & $\begin{array}{c}\text { Mea } \\
\mathbf{n}\end{array}$ & Median & $\begin{array}{c}\text { Std } \\
\text { Dev } \\
\text { iasi }\end{array}$ \\
\hline $\begin{array}{l}\text { Sebelum } \\
\text { terapi } \\
\text { origami }\end{array}$ & $1-2$ & 1,93 & 2,00 & 0,2 \\
$\begin{array}{l}\text { Sesudah } \\
\text { terapi } \\
\text { origami }\end{array}$ & $0-2$ & 1,20 & 1,00 & 58 \\
\hline
\end{tabular}

Berdasarkan tabel 4 diatas dapat dilihat bahwa rata-rata tingkat kecemasan sebelum diberikan terapi bermain origami yaitu 1,93 sedangkan rata-rata tingkat kecemasan sesudah diberikan terapi yaitu 1,20 .

\section{Analisis Bivariat}

Berikut ini disajikan hasil analisis Wilcoxon Signed-Rank Test seperti ditunjukkan pada tabel 5 di bawah ini:

Tabel 5. Analisa data pengaruh terapi bermain origami terhadap penurunan tingkat kecemasan pada anak prasekolah yang menjaalani hospitalisasi

\begin{tabular}{|c|c|c|c|c|c|}
\hline $\begin{array}{l}\text { Vari } \\
\text { able }\end{array}$ & Rank & $\mathbf{N}$ & $\begin{array}{c}\text { Mea } \\
\text { n } \\
\text { rank }\end{array}$ & $\begin{array}{c}\text { Sum } \\
\text { of } \\
\text { rank }\end{array}$ & $\begin{array}{c}\text { Sig. } \\
2- \\
\text { tailed }\end{array}$ \\
\hline \multirow{4}{*}{$\begin{array}{l}\text { Sebel } \\
\text { um - } \\
\text { sesud } \\
\text { ah }\end{array}$} & Negatif & 10 & 5,50 & 55,00 & 0,002 \\
\hline & rank & & 0,00 & 0,00 & \\
\hline & Positif & 0 & & & \\
\hline & Ties & 5 & & & \\
\hline
\end{tabular}

diperoleh hasil uji hipotesis nilai $\mathrm{p}=0,002$ $(<0,05)$ artinya hal ini menunjukkan bahwa H0 ditolak yang berarti terdapat perbedaan tingkat kecemasan anak sebelum dan sesudah diberikan terapi origami. Dengan demikian terapi bermain origami berpengaruh terhadap penurunan tingkat kecemasan pada anak prasekolah yang menjalani hospitalisasi.

\section{Pembahasan}

Tingkat kecemasan anak usia pra sekolah yang menjalani prosedur invasif infus saat hospitalisasi sebelum dan 
JOURNAL OF NURSING EDUCATION AND PRACTICE,

VOL. 01 NO. 01 DESEMBER 2020
Ciptaan disebarluaskan di bawah

Lisensi Creative Commons Atribusi-

NonKomersial-BerbagiSerupa 4.0 setelah pemberian terapi bermain origami

Tingkat kecemasan sebelum dilakukan intervensi pada kelompok terapi bermain origami, hampir seluruhnya responden $(93,3 \%)$ memiliki kecemasan berat dan tidak ada satupun responden yang mengalami kecemasan ringan $(0 \%)$. Pada kelompok intervensi setelah diberikan terapi bermain origami, sebagian besar responden mengalami kecemasan sedang $(66,7 \%)$ dan terdapat satu responden $(6,7 \%)$ yang mengalami kecemasan ringan serta masih ada 4 responden (26.7\%) yang mengalami tingkat kecemasan berat. Berdasarkan distribusi frekuensi dari hasil pada tabel tersebut dapat disimpulkan bahwa tingkat kecemasan anak mengalami penurunan sesudah diberikan intervensi terapi bermain origami.

Pada penelitian ini, kertas origami yang diberikan pada anak berupa kertas lipat berwarna-warni dengan tujuan anak bisa mengenal berbagai macam warna dan mengalihkan perhatian anak ketika sedang rewel atau cemas. Selain itu, supaya anak lebih kooperatif terhadap tindakan yang diberikan. Permainan origami dilakukan di tempat tidur yang melibatkan orang tua dengan didampingi peneliti. Proses awal yang dihadapi peneliti adalah pendekatan pada anak yang cukup membutuhkan waktu dan kesabaran dalam membina trust dengan anak sampai anak ada kemauan untuk bermain. Sebelum diberikan terapi bermain origami, nilai total skor dari tingkat kecemasan anak bervariasi dan kebanyakan berada pada tingkat kecemasan berat bahkan berat sekali. Tetapi setelah diberikan terapi bermain origami rata-rata tingkat kecemasan anak bervariasi dan mengalami penurunan pada tingkat kecemasan sedang dan ringan.

Hasil analisis univariat yang sama dilakukan oleh Ramdaniati \& Hermaningsih, (2016) pada penelitiannya sebelum memberikan terapi menunjukkan bahwa $52 \%$ anak pra-sekolah mengalami kecemasan sedang, diikuti dengan kecemasan ringan dan tidak ada kecemasan sebanyak $32 \%$ dan sebanyak $16 \%$. Kondisi ini berubah setelah Intervensi dalam bentuk teka-teki selama 30 menit selama 2 hari. Sebagian besar anak-anak (64\%) mengalami kecemasan dan hanya (36\%) responden mengalami kecemasan ringan.

Hal ini sesuai dengan hasil penelitian Suryanti \& Yulistiani, (2011) yang menunjukkan adanya penurunan tingkat kecemasan sebelum dan sesudah 
JOURNAL OF NURSING EDUCATION AND PRACTICE,

VOL. 01 NO. 01 DESEMBER 2020
Ciptaan disebarluaskan di bawah

Lisensi Creative Commons Atribusi-

NonKomersial-BerbagiSerupa 4.0

Internasiona

\section{bermain origami di ruang anak RSUD 45 \\ Kuningan.}

Berdasarkan hasil uji statistik perbedaan tingkat kecemasan sebelum dan sesudah pemberian terapi bermain pada responden dengan menggunakan uji wilcoxon didapatkan nilai p sebesar 0,002 . Hal ini menunjukkan bahwa $\mathrm{p}<0,05$ sehingga Ha diterima dan Ho ditolak yang berarti ada perbedaan tingkat kecemasan sebelum dan sesudah diberikan terapi bermain origami pada anak yang menjalani prosedur invasif infus di Ruang anak RSUD 45 Kuningan. Ini berarti bahwa terapi bermain dengan menggunakan origami bisa mengurangi tingkat kecemasan anak usia pra sekolah yang dibuktikan dengan respon anak mulai kooperatif dan tampak tenang terhadap kehadiran petugas kesehatan.

Hasil observasi dan wawancara peneliti menurut ibu dan responden sebelum sakit responden bisa membuat origami berupa kapal-kapalan. Pada permainan origami di rumah sakit responden mengalami sedikit kesulitan membuat origami kapal-kapalan karena keterbatasan gerak dimana tangannya

\section{terpasang infus sehingga hanya menggunakan satu tangan dan dibantu oleh orang tua. Permainan origami dapat \\ Perbedaan tingkat kecemasan anak sebelum dan sesudah intervensi terapi}


JOURNAL OF NURSING EDUCATION AND PRACTICE,

VOL. 01 NO. 01 DESEMBER 2020
Ciptaan disebarluaskan di bawah

Lisensi Creative Commons Atribusi-

NonKomersial-BerbagiSerupa 4.0 digunakan untuk mengajarkan keterampilan pada anak usia prasekolah karena gerakan melipat kertas selain dapat mengembangkan daya cipta juga dapat mengembangkan sistem saraf motorik. Origami merupakan permainan yang dapat diterapkan pada anak usia prasekolah yang mengalami hospitalisasi karena sesuai dengan prinsip permainan yang ada di rumah sakit yaitu tidak membutuhkan energi banyak, singkat, sederhana, aman dan murah (Damayanti, 2011).

$$
\text { Raman \& Singhal, }
$$
berpendapat bahwa terapi bermain adalah terapi modalitas perkembangan yang sensitif didasarkan pada keyakinan bahwa bermain merupakan media alami untuk anak-anak. Terapi bermain membantu anakanak prasekolah untuk meningkatkan keterampilan sosial, emosional, dan perilaku. Hal ini juga memberikan manfaat bagi anak-anak untuk mengurangi tingkat ketakutan dan kecemasan, serta meningkatkan komunikasi dan keterampilan dalam meningkatkan harga diri mereka (Sezici et al., 2017).

\section{Hasil penelitian sebelumnya} menunjukkan bahwa terdapat pengaruh terapi origami terhadap tingkat kecemasan pada anak prasekolah dengan hospitalisasi (Sadiah et al., 2014).

\section{Daftar Pustaka}

Andriana, D. (2011). Tumbuh Kembang dan Terapi Bermain pada Anak. Jakarta: Salemba Medika.

Ball, J. ., \& Bindler, R. . (2013). Paediatric Nursing: Caring For Children. New Jearsey. Prentice Hall.

Boseman, L. (2017). Atraumatic Care: A Device To Reduce Pain In The Pediatric Population During Painful Ambulatory Procedures. Association of Child life Professionals. Child Life News.

Bsiri-Moghaddam, K., Basiri-Moghaddam, M., Sadeghmoghaddam, L., \& Ahmadi, F. (2011). The concept of hospitalization of children from the view point of parents and children. Iranian Journal of Pediatrics, 21(2), 201.

Damayanti, A. (2011). Ayo Melipat Origami. Yogyakarta: Cahaya Atma Pustaka.

Gomes, G. L. L., Fernandes, M. das G. M., \& Nóbrega, M. M. L. da. (2016). Hospitalization anxiety in children: conceptual analysis. Revista Brasileira de Enfermagem, 69(5), 940-945.

Hockenberry, M., \& Wilson, D. (2015). Wong's Nursing Care Of Infant And Children 10th Edition. Mosby Elsevier.

Homeyers, L., \& Morrison, M. (2008). Play Therapy, practice. Issues and Trends. 
JOURNAL OF NURSING EDUCATION AND PRACTICE,

VOL. 01 NO. 01 DESEMBER 2020

the Board of Trustees of the Universsity of Illinois.

Kaluas, I., Ismanto, A. Y., \& Kundre, R. M. (2015). Perbedaan Terapi Bermain Puzzle Dan Bercerita Terhadap Kecemasan Anak Usia Prasekolah (3-5 Tahun) Selama Hospitalisasi Di Ruang Anak RS TK. III. Rw Mongisidi Manado. Jurnal Keperawatan, 3(2).

Kozier, B. (2010). Buku Ajar Fundamental Nursing. Jakarta: EGC.

Kozlowski, L. J., \& Monitto, C. . (2013). Pain in Hospitalized Children. Pediatrics for Parents, 29(5), 24-25.

Mediani, H . (2017). Evidence Based Practice Tentang Therapeutic Play Pada Anak Yang Menjalani Hospitalisasi. Disampaikan pada seminar keperawatan. Pentingnya Bermain Bagi Anak yang Mengalami Hospitalisasi. Bandung 28 Januari 2017.

Nabors, L., Bartz, J., Kichler, J., Sievers, R., Elkins, R., \& Pangallo, J. (2013). Play as a mechanism of working through medical trauma for children with medical illnesses and their siblings. Issues in Comprehensive Pediatric Nursing, 36(3), 212-224.

Notoatmodjo, S. (2010). Metode Penelitian Kesehatan. Jakarta: Rineka Cipta.

Obaid, K. B. (2015). Psychosocial Impact of Hospitalization on Ill Children in Pediatric Oncology Wards. J Nurs Health Scien.[on-Line], 4(3), 72-78.

Polit, F, D., \& Beck, C. T. (2014). Essentials of Nursing Research: Appraising Evidence for Nursing
Ciptaan disebarluaskan di bawah

Lisensi Creative Commons Atribusi-

NonKomersial-BerbagiSerupa 4.0 Internasional. (c) () ()

Practice 8th Edition. Philadephia: Lippincott William \& Wilkins.

Potter, P. ., Perry, A. ., Stockert, P. ., \& Hall, A. . (2014). Canadian fundamentals of nursing (5th Cdn. ed.) (J. C. Ross-Kerr, M. J. Wood, B. J. Astle \& W. Duggleby, Cdn. Adapt.). Toronto: Elsevier Canada.

Raman, V., \& Singhal, M. (2015). Play therapy with children: Its relevance and utility in the Indian context. Journal of Indian Association for Child \& Adolescent Mental Health, 11(2).

Ramdaniati, S., \& Hermaningsih, S. (2016). Comparison study of art therapy and play therapy in reducing anxiety on pre-school children who experience hospitalization. Open Journal of Nursing, 6(01), 46.

Sadiah, R. H., Hardiani, R. S., \& Rondhianto, R. (2014). Pengaruh Terapi Bermain Origami terhadap Tingkat Kecemasan pada Anak Prasekolah dengan Hospitalisasi di Ruang Aster RSD dr. Soebandi Jember (The Effect of Origami Play Therapy toward Anxiety Level on Preschool Age Children Hospitalization in Aster's Room. Pustaka Kesehatan, 2(3), 530-536.

Sezici, E., Ocakci, A. F., \& Kadioglu, H. (2017). Use of play therapy in nursing process: A prospective randomized controlled study. Journal of Nursing Scholarship, 49(2), 162-169.

Silva, R. D. M. da, Austregésilo, S. C., Ithamar, L., \& Lima, L. S. de. (2017). Therapeutic play to prepare children for invasive procedures: a systematic 
JOURNAL OF NURSING EDUCATION AND PRACTICE, VOL. 01 NO. 01 DESEMBER 2020

review. Jornal de Pediatria, 93(1), 616.

Sugiyono. (2014). Satistika Untuk Penelitian. Bandung: Alfabeta.

Suryanti, S., \& Yulistiani, M. (2011). Pengaruh Terapi Bermain Mewarnai Dan Origami Terhadap Tingkat Kecemasan Sebagai Efek Hospitalisasi Pada Anak Usia Pra Sekolah di RSUD dr. R. Goetheng Tarunadibrata, Purbalingga. Jurnal Kesehatan Samodra Ilmu, 3, 73-80.

Utami, Y. (2014). Dampak hospitalisasi terhadap perkembangan anak. Jurnal Ilmiah WIDYA, l(1).
Ciptaan disebarluaskan di bawah

Lisensi Creative Commons Atribusi- 